\title{
Photosynthesis of boreal ground vegetation after a forest clear-cut
}

\author{
L. Kulmala ${ }^{1}$, J. Pumpanen ${ }^{1}$, T. Vesala ${ }^{2}$, and P. Hari ${ }^{1}$ \\ ${ }^{1}$ Department of Forest Ecology, University of Helsinki, Finland \\ ${ }^{2}$ Department of Physics, University of Helsinki, Finland
}

Received: 8 April 2009 - Published in Biogeosciences Discuss.: 5 May 2009

Revised: 26 September 2009 - Accepted: 8 October 2009 - Published: 6 November 2009

\begin{abstract}
Heather (Calluna vulgaris), rosebay willowherb (Epilobium angustifolium), wavy hair-grass (Deschampsia flexuosa) and raspberry (Rubus idaeus) are typical species at boreal clear-cut sites. In this study, we measured their photosynthesis separately in the growing season of 2005 using a manual chamber. All measured species showed clear and species-specific seasonal cycles of photosynthetic activity $\left(P_{\max }\right)$. The maxima of $C$. vulgaris and E. angustifolium occurred around June and July, while that of $R$. idaeus occurred as late as August. A simple model of photosynthetic activity is presented, addressing the photosynthesis of $C$. vulgaris was mainly explained by temperature history when the soil moisture is high. The activity of deciduous D. flexuosa also followed the temperature history, unlike the activities of E. angustifolium and R. idaeus. During a short drought, some shoots decreased their $P_{\max }$ levels but none of the species showed similar reactions between individuals. We also observed that the comparison of the whole-plant $P_{\max }$ or respiration of different-sized individuals were less scattered than the results based on full-grown leaf mass, implying that species-specific rates of photosynthesis at ground level are rather similar regardless of the plant size. Using species composition and continuous temperature and light measurements, we upscaled the species-specific process rates and integrated fixed and respired $\mathrm{CO}_{2}$ of ground vegetation for the entire 2005 growing season. The photosynthetic production per surface area of soil was $760 \mathrm{~g} \mathrm{C} \mathrm{m}^{-2} \mathrm{y}^{-1}$ at the fertile site and $300 \mathrm{~g} \mathrm{C} \mathrm{m}^{-2} \mathrm{y}^{-1}$ at the infertile site. During the snowfree period (18 April-21 November), the above ground parts of measured species released $75 \mathrm{~g} \mathrm{C} \mathrm{m}^{-2} \mathrm{y}^{-1}$ at the infertile site. At the fertile site, E. angustifolium and $R$. idaeus respired 22 and $12 \mathrm{~g} \mathrm{C} \mathrm{m}^{-2} \mathrm{y}^{-1}$, respectively.
\end{abstract}

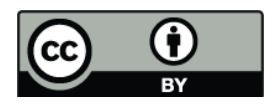

Correspondence to: L. Kulmala (liisa.kulmala@helsinki.fi)

\section{Introduction}

Current climate scenarios suggest that the global mean temperature will increase due to increased concentrations of greenhouse gases such as carbon dioxide $\left(\mathrm{CO}_{2}\right)$ in the atmosphere (IPCC, 2007). The increase is predicted to be the largest in the highest latitudes and may result in serious consequences to the present vegetation. These scenarios have resulted in several studies on vegetation and plant processes related to $\mathrm{CO}_{2}$ exchange, i.e. photosynthesis and respiration.

Until recently, research on $\mathrm{CO}_{2}$ fixation has focused mainly on trees. However, due to timber harvesting 282000 ha $(1.4 \%)$ of the forests in Finland are completely treeless and 3264000 ha $(16.1 \%)$ of forests are younger than $20 \mathrm{y}$ (Metla, 2004). Therefore, a significant part of these forests is in the early phase of succession when forests turn from high $\mathrm{CO}_{2}$ source into a high sink. Upon clear-cutting, the amount of decomposing material is increased and species composition as well as environmental conditions are changed dramatically. The effect of these changes on carbon balance is not adequately known in order to predict the long term effects of forest harvesting on soil or atmospheric carbon stocks (Johnson and Curtis, 2001).

During the first phases of succession, the number of vascular plant species is high (e.g. Pykälä, 2004) and the irradiation environment is unshaded. Opportunistic, shadeintolerant, nutrient-demanding and fast-growing vascular plant species dominate before more competitive trees eliminate or reduce the role of opportunistic species at ground level. The succession patterns and ecology of ground vegetation are well studied, but the photosynthesis of the different species in the ground vegetation is still poorly known.

Different species have species-specific strategies for competing and surviving in their natural growing environments. For example, deciduous species are effective $\mathrm{CO}_{2}$ assimilators (Chabot and Hicks, 1982), but their growing season is shorter than the season for perennial species that, at the same

Published by Copernicus Publications on behalf of the European Geosciences Union. 
Table 1. Average species-specific tree height $(\mathrm{m})$, tree density $\left(\mathrm{ha}^{-1}\right)$, and the depth of organic and A horizons $(\mathrm{mm})$ at the study sites.

\begin{tabular}{lcc}
\hline & $\begin{array}{c}\text { Infertile } \\
\text { site }\end{array}$ & $\begin{array}{c}\text { Fertile } \\
\text { site }\end{array}$ \\
\hline Organic layer depth (mm) & 45.7 & 65.4 \\
A horizon depth (mm) & 57.6 & 75.0 \\
Average height of Pinus sylvestris $(\mathrm{m})$ & 0.9 & 0.4 \\
Number of Pinus sylvestris $\left(\mathrm{ha}^{-1}\right)$ & 1200 & 1800 \\
Average height of Picea abies $(\mathrm{m})$ & 0.15 & 0.4 \\
Number of Picea abies $\left(\mathrm{ha}^{-1}\right)$ & 200 & 5000 \\
Average height of Betula $(\mathrm{m})$ & 1.2 & 1.5 \\
Number of Betula $\left(\mathrm{ha}^{-1}\right)$ & 710 & 16000 \\
\hline
\end{tabular}

time, require longer periods to produce carbon gain due to slow development, costly production and low photosynthetic production (Chabot and Hicks, 1982). A considerable fraction of the carbon fixed in photosynthesis is lost as $\mathrm{CO}_{2}$ during respiration that serves many important functions, such as the supply of energy. The temperature dependence of respiration is influenced by species and growth habit (Taiz and Zeiger, 2002). These species-specific activities in fixing and releasing $\mathrm{CO}_{2}$, generate a need to study the species separately for a reliable extrapolated estimate for photosynthetic production as well as for a prediction of the future production in the possibility of changed species composition.

In traditional studies of $\mathrm{CO}_{2}$ exchange, chamber measurements are made over a small area with natural species composition, hence, the contributions of different species remain unclear. These studies face uncertainties in scaling point measurements of a larger area (e.g. at the ecosystem level) because the ground vegetation usually is very heterogeneous, even at small spatial scales (Jalonen et al., 1998; Palviainen et al., 2005; Riutta et al., 2007; Kulmala et al., 2008). Some ecosystem net $\mathrm{CO}_{2}$ exchange studies at young forests of various types have been carried out with the eddy covariance (EC) technique. These studies are mainly concerning the size of the carbon sink or source but the detailed analysis of the flux components indicate that the photosynthetic production of ground vegetation is substantial (e.g. Rannik et al., 2002; Kolari et al., 2004; Humphreys et al., 2006; Fredeen et al., 2007). However, the EC measurements are also unable to separate the contribution of different species and detect changes in their species-specific photosynthetic activity. In this study, we measured common species separately with a manual chamber to clarify the species-specific activity in fixing and releasing $\mathrm{CO}_{2}$.

The aim of the present work, is to study the photosynthesis and respiration of most common early-successional species. We (1) measured the net $\mathrm{CO}_{2}$ exchange and its components, photosynthesis and respiration of widespread species sepa- rately during one growing season at two 5-y-old clear-cut sites in southern Finland and (2) studied the relationship between the exchange components and the environmental factors. One of the studied sites was very fertile, with fastgrowing and opportunistic dominant species having rapidly reproducing new tissues. The other site is nutrient-poor and the dominant species are evergreen and grow slowly. At both sites, we (3) quantified the cumulative annual production by upscaling the processes with species composition and environmental factors for an entire growing season to provide estimates of the carbon sequestration potential of the ground vegetation in young boreal forests.

\section{Materials and methods}

\subsection{Study sites}

We measured the $\mathrm{CO}_{2}$ exchange of the most common forest floor species at two flat clear-cut sites located approx. $1 \mathrm{~km}$ from each other and approx. $7 \mathrm{~km}$ from the station for measuring ecosystem-atmosphere relations (SMEAR II, Hari and Kulmala, 2005) in Hyytiälä, southern Finland $\left(61.52^{\circ} \mathrm{N}\right.$, $24.17^{\circ} \mathrm{E}$ ). Both sites were approximately 1 hectare in size. According Climatological statistics of Finland, the annual mean temperature in the area was $+2.9^{\circ} \mathrm{C}$ and precipitation $709 \mathrm{~mm}$ during the time period from 1960 to 2000 (Drebs et al., 2002). January was the coldest month (mean $-8.9^{\circ} \mathrm{C}$ ) and July the warmest (mean $+15.9^{\circ} \mathrm{C}$ ).

The soil type at both of the study sites is a Haplic podzol in the FAO-Unesco (Food and Agriculture Organization - United Nations Educational, Scientific and Cultural Organization) soil classification system (FAO-Unesco, 1990). The bedrock is mainly acidic granite, granodiorite and micagneiss with some small intrusions of gabbro and peridotite. The experimental sites differed substantially in fertility. The parent material of the soil is glaciofluvial deposits at the infertile site. At the fertile site, the soil is glacial till. Both the organic layer and A horizon were deeper at the fertile site than at the infertile site (Table 1). The fertile site belonged mainly to the Myrtillus type (MT) and partly to Oxalis Myrtillys type (OMT), according to the Cajanderian forest site type classification (Cajander, 1926). The infertile type belonged to Calluna type (CT).

The soil at the sites had been scarified in the year following clear-cutting according to the forestry guidelines of the Finnish National Board of Forestry. The fertile site was planted with Norway spruce and the infertile site was sown with Scots pine seeds (Table 1). The amount of Silver birch seedlings of natural origin was substantial at the fertile site. The tree seedlings were approximately 5 years old at both sites in summer 2005 when we performed the fieldwork.

Fast-growing and opportunistic dominant species having rapidly reproducing new tissues, such as wavy hairgrass (Deschampsia flexuosa (L.) Trin.), rosebay willowherb 
(Epilobium angustifolium (L.) Holub) and raspberry (Rubus idaeus L.), dominated at the fertile site. The dominant species at the infertile site were evergreen and slow-growing. Heather (Calluna vulgaris (L.) Hull), mountain crowberry (Empetrum nigrum L.) and mosses (mainly Pleurozium schreberi (Willd. ex Brid.) Mitt.) dominated the ground vegetation, with some sparse growth of E. angustifolium.

To upscale the measured activity of photosynthesis, we continuously measured PAR (photosynthetically active radiation) with a LI-190 (LI-COR Biosciences, Lincoln, NE, USA) at the SMEAR II station above the canopy. Due to the lack of shade and close distance, PAR at the SMEAR is similar to the average radiation at the clear-cut sites. Soilwater tension in the mineral soil was measured manually at approx. 2-week intervals, using a Tensicorder (Soil Measurement Systems (TX), Tuscon, AZ, USA) and 10 tensiometers Soil Measurement Systems) at a depth of $3 \mathrm{~cm}$. The tensiometers were located next to each experimental shoot.

We measured the air temperature at a $2-\mathrm{m}$ height at the open Siikaneva fen in southern Finland $\left(61.48^{\circ} \mathrm{N}, 24.09^{\circ} \mathrm{E}\right)$ at the same altitude from sea level as the studied clear-cut sites. Siikaneva is approx. $5 \mathrm{~km}$ west of the SMEAR II and $4 \mathrm{~km}$ from the clear-cut sites. There were some gaps (26 May-1 June, 7 July-5 August, 9 August-18 August, 30 August-16 September) in the measured temperature series that were filled with temperature readings from a $16-\mathrm{m}$ height at the SMEAR II station. In general, the temperatures at the SMEAR II and at the Siikaneva fen were very similar except for spring and early summer when the night temperatures were cooler at the open fen than at the SMEAR II. Soil temperature was continuously measured with three temperature sensors (iButton ${ }^{\circledR}$, Maxim Integrated products Inc., Sunnyvale, CA) at 60-min interval at a depth of $3 \mathrm{~cm}$ at both study sites from 16 May to 26 November in 2005.

\subsection{Sampling of vegetation}

We estimated the average biomass of ground vegetation at the sites by systematically collecting aboveground samples of forest floor vegetation from an area of $300 \mathrm{~m}^{2}$. The number of samples was 20 and 19 at the infertile and fertile sites, respectively. The samples were collected systematically at 5$\mathrm{m}$ intervals on four lines $5 \mathrm{~m}$ apart. One sample was $0.090 \mathrm{~m}^{2}$ in size. We separated each sample into different species and each dwarf shrub species into leaves and stems. These segments were weighed after drying at $60^{\circ} \mathrm{C}$ for $24 \mathrm{~h}$.

\subsection{Chamber measurements of $\mathrm{CO}_{2}$ exchange}

A manual chamber, based on the closed dynamic chamber technique, was used for measuring the light response curves of $\mathrm{CO}_{2}$ exchange of two shoots of both Epilobium angustifolium and Calluna vulgaris at the infertile site and two shoots of Epilobium angustifolium and Rubus idaeus and two populations of Deschampsia flexuosa at the fertile site.
The experimental shoots of $C$. vulgaris as well as the populations of $D$. flexuosa differed significantly in size. The measurements were begun on 2 June and ended on 24 October 2005. All of the measurements were performed between 08:00 and 13:00 but we varied the measurement order among the shoots. We repeated the light response measurements at approx. 2-week intervals.

The chamber was made of 5-mm-thick transparent Plexiglas $0.30 \mathrm{~m}$ in diameter, $0.30 \mathrm{~m}$ in height and open downwards. During the measurements, the chamber was placed on a polyvinylchloride (PVC) collar that was perforated to allow air to circulate freely under the chamber. There was a 1-cm-thick sheet of cellular plastic between the collar and the chamber. The shoots entered the chamber through a cut in the plastic. Hence, we could measure the same shoots several times in their natural growing environment without causing any change or disturbance to the shoots. Some of the shoots grew taller than $30 \mathrm{~cm}$ and in this case, we used an otherwise identical chamber but $0.40 \mathrm{~m}$ in height. Deschampsia flexuosa was measured with the higher chamber but no cellular plastic was used as a bottom. A solid, plastic collar was placed in the soil and the shoots freely entered the chamber. The measurement signal was then a sum of the soil $\mathrm{CO}_{2}$ efflux and photosynthesis of $D$. flexuosa.

The $\mathrm{CO}_{2}$ concentration inside the chamber was monitored during the measurement with a $\mathrm{CO}_{2}$ probe based on a nondispersive infrared sensor (NDIR) technique (GMP343, Vaisala Corporation, Vantaa, Finland) attached inside the chamber. The $\mathrm{CO}_{2}$ concentration readings were recorded at 5-s intervals and corrected automatically for humidity, temperature and pressure with a data recorder (MI70, Vaisala Corporation). The humidity and temperature values used in the correction were obtained from a temperature and humidity probe (HMP75; Vaisala Corporation) attached inside the chamber and connected to the MI70 data recorder. Atmospheric pressure was continuously monitored at the SMEAR II station. A small fan was used to mix the air inside the chamber. Instantaneous irradiation was measured with a PAR sensor (LI190, LI-COR Biosciences) attached outside the chamber following the test confirming that the Plexiglas does not significantly capture incoming light. The rate of $\mathrm{CO}_{2}$ exchange was estimated from a linear regression fitted to $\mathrm{CO}_{2}$ readings over a 3-min time. The measuring period was shortened to $1 \mathrm{~min}$ in high PAR radiation during high photosynthetic activity to avoid heating the chamber.

One set of measurements consisted of four to six measurements with different light intensities and one dark measurement. Between the measurements, the chamber was ventilated by carefully raising it up from the experimental shoot. The highest light intensity was direct sunlight and the other three to five light intensities were created by shadowing the chamber with layers of netted fabric. The chamber was fully darkened with an aluminium cover during the last measurement. After the campaign, the aboveground parts of the measured plants were collected, dried for $24 \mathrm{~h}$ at $60^{\circ} \mathrm{C}$ and 
weighed to obtain the leaf and total biomass.

Photosynthesis is driven by light but the relationship between light and the photosynthetic rate is saturating because the availability of $\mathrm{CO}_{2}$ is limited in high light intensities. Respiration accompanies the observable $\mathrm{CO}_{2}$ exchange in the daytime. Therefore, we fitted a Michaelis-Menten-type equation (Michaelis and Menten, 1913) for each set of our measurements as follows:

$N E_{i}(I)=\frac{P_{\max , i} I}{b_{i}+I}-r$

In the equation, $i$ is the species measured (Deschampsia flexuosa, Calluna vulgaris, Epilobium angustifolium, Rubus idaeus), $N E_{i}(I)$ is the species-specific full-grown leaf massbased $\left(\mathrm{g}_{\mathrm{CO}_{2}} \mathrm{~g}^{-1} \mathrm{~h}^{-1}\right)$ or the shoot-based rate of $\mathrm{CO}_{2}$ exchange $\left(\mathrm{g}_{\mathrm{CO}_{2}} \mathrm{~h}^{-1}\right), I$ is the light intensity $\left(\mu \mathrm{mol} \mathrm{m}^{-2} \mathrm{~s}^{-1}\right)$, $b$ is the light intensity ( $\mu \mathrm{mol} \mathrm{m}^{-2} \mathrm{~s}^{-1}$ ) when the assimilation rate is half the rate of light-saturated assimilation, $r$ is the rate of dark respiration and $P_{\max , i}$ is the rate of light-saturated assimilation per full-grown leaf mass $\left(\mathrm{g}_{\mathrm{CO}_{2}} \mathrm{~g}^{-1} \mathrm{~h}^{-1}\right)$ or per individual shoot $\left(\mathrm{g}_{\mathrm{CO}_{2}} \mathrm{~h}^{-1}\right)$, i.e. photosynthetic activity. In the whole plant measurements as here, the photosynthetic activity indicates both the changes in the photosynthesizing leaf area and the amounts and catalytic activities of photosynthetic enzymes (Pearcy et al., 1987).

Van't Hoff noted already in 1884 that the chemical reactions in a plant are dependent on temperature. The dependence is often described as an exponential function and, therefore, we fitted an exponential model of species-specific temperature dependence, $R_{i}(T)$, into the $r$ values (Eq. 1) and instantaneous temperature $\left(T,{ }^{\circ} \mathrm{C}\right)$ measured during the photosynthesis measurement as follows:

$R_{i}(T)=r_{0, i} Q_{10, i}^{\frac{T}{10}}$

where $Q_{10, i}$ and $r_{0, i}$ are species-specific parameters.

In boreal region, there is a clear seasonal cycle in photosynthesis. We were interested, if it is possible to model the changes in the rate of photosynthesis for future applications. We used a function called state of development, $S\left({ }^{\circ} \mathrm{C}\right.$, Pelkonen and Hari, 1980; Mäkelä et al., 2004) that follows temperature with a time constant $\tau$ :

$\frac{d S}{d t}=\frac{T(t)-S}{\tau}$

where $T(t)$ is temperature $\left({ }^{\circ} \mathrm{C}\right)$ at moment $t$. As the temperature, we used hourly averages that were measured at $\mathrm{Si}$ ikaneva. The initial value of $S$ was set to be the first value of temperature when the estimation was begun on 1 April 2005. We tested different values of $\tau$ and found that $150 \mathrm{~h}$ appeared to be the best value.

The estimated daily photosynthetic activity, $\bar{P}_{\max , i}$, was assumed to follow the $S$ values. The highest estimated $\bar{P}_{\max , i}$ was set to the highest measured species-specific $P_{\max , i}$ value on the measuring date $\left(t_{\max , i}\right)$. Other daily values were estimated by the relationship between the daily $S(t)$ value and $S\left(t_{\max , i}\right)$ as follows:

$\bar{P}_{\max , i}(t)=\frac{S(t)}{S\left(t_{\max , i}\right)} P_{\max , i}\left(t_{\max , i}\right)$

If $S(t)$ was smaller than $0^{\circ} \mathrm{C}, \bar{P}_{\max , i}(t)$ was set to zero.

The above model of state of development described properly only the measurements of Calluna vulgaris and Deschampsia flexuosa. Therefore, we estimated the speciesspecific daily $\bar{P}_{\mathrm{max}, i}(t)$ values for Epilobium angustifolium and Rubus idaeus by interpolating the intermediate values from the measured average $P_{\max , i}$ values.

\subsection{Upscaling GPP and $R_{e}$}

We upscaled the mass-based and species-specific parameters of photosynthesis (Eq. 1) over the whole site using leaf biomass achieved from the sampling. To estimate the assimilation over the entire season, $P_{e}$, we integrated the momentary photosynthetic rates by the continuous PAR measurements above the SMEAR II canopy:

$P_{e}=\sum_{i} \int_{t_{1}}^{t_{2}} m_{i} \frac{\bar{P}_{\mathrm{max}, i}(t) I(t)}{b_{i}+I(t)} d t$

where $m_{i}$ is the areal average of full-grown leaf mass of species $i, \bar{P}_{\text {max }, i}(t)$ and $b_{i}$ the species-specific parameters and $I(t)$ the PAR intensity (30-min average) measured at the SMEAR II station. We upscaled the $P_{e}$ over the time period starting from 18 April $\left(t_{1}\right)$ until 21 November $\left(t_{2}\right)$.

For the estimation of released carbon dioxide, $R_{e}$, we integrated and summed the species-specific respiration rates

$R_{e}=\sum_{i} \int_{t_{1}}^{t_{2}} m_{t o t, i} R_{i}(T(t)) d t$

where $m_{\mathrm{tot}, i}$ is the species-specific total aboveground mass, also including the stems of small shrubs, $R_{i}(T(t))$ the model of temperature dependence (Eq. 2) and $T$ the temperature.

\section{Results and discussion}

\subsection{Weather in 2005}

The weather was fairly typical during the snow-free period in 2005. The snow had melted entirely by 18 April 2005 at the SMEAR II site. The daily average air temperatures at the open Siikaneva fen had begun to fluctuate above zero in late March after being below zero for several months (Fig. 1a). This cool period lasted until early May when the daily average temperatures began to increase, remaining above $10^{\circ} \mathrm{C}$ for 1 week. Another cool period followed thereafter. The daily average temperature crossed $10^{\circ} \mathrm{C}$ in early June. From 


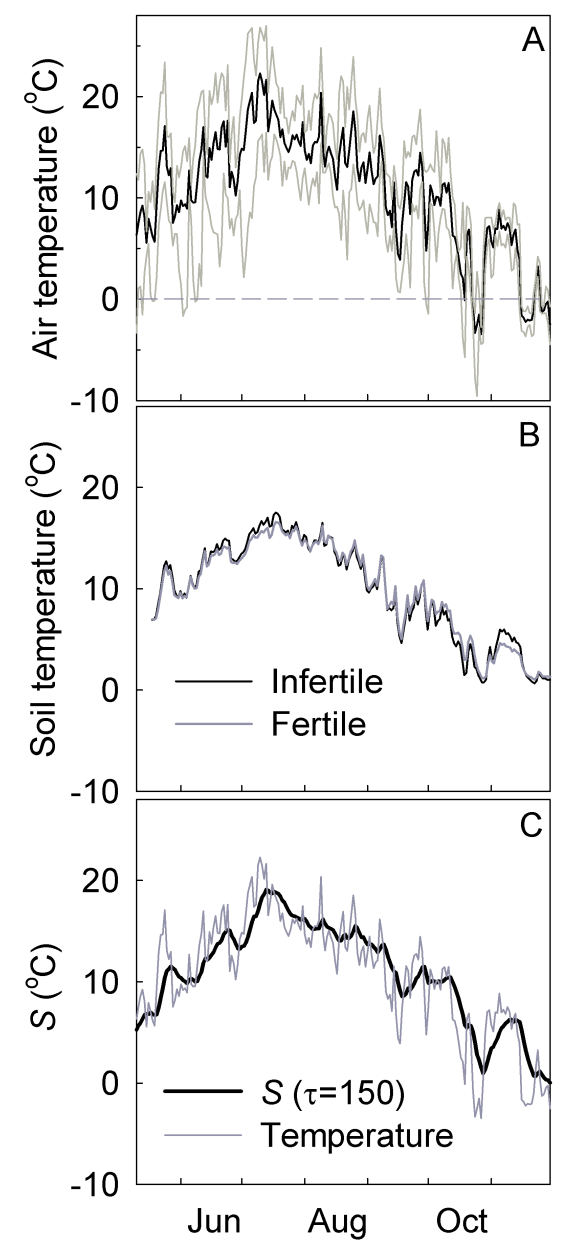

Fig. 1. (A) Daily average (black line), minimum and maximum air temperatures (grey lines) measured at neighbouring Siikaneva fen between 10 May and 1 December 2005. (B) Daily average soil temperatures measured between the $\mathrm{H}$ and $\mathrm{A}$ horizons at the clear-cut sites. (C) State of development (S, bold line) follows temperature (thin line) with a time constant of $\tau$ (here $\tau=150 \mathrm{~h}$ ).

late June to early July, there was again a colder and rainy week, after which the average and maximum temperatures increased again, but the minimum temperatures were as low as $2^{\circ} \mathrm{C}$ ( 2 July). The average temperature began to decrease slowly in mid-July but crossed $0^{\circ} \mathrm{C}$ for the first time as late as 19 October but the minimum temperatures had already been very close to zero in mid-September and crossed it for the first time on 29 September. The first snow appeared at SMEAR II on 24 October and became permanent on 21 November. During the snow-free period, the modelled state of development (Eq. 3, $\tau=150 \mathrm{~h}$, Fig. 1c) followed the air temperature.

Soil temperatures affect biomass allocation (DeLucia et al., 1992), root growth (Ryyppö et al., 1998) and nutrient uptake. At the sample sites, the measured soil temperature closely followed the average air temperature attaining a max-

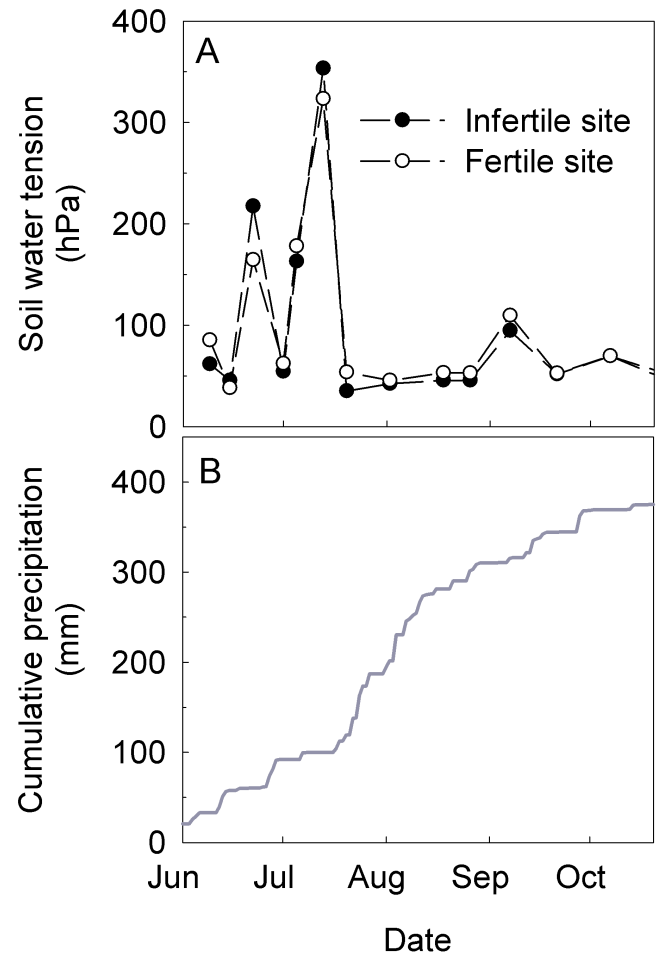

Fig. 2. Soil-water tension at both clear-cut sites (A) and cumulative precipitation (B) measured at the SMEAR II station above the canopy between 1 May and 1 December 2005.

imum $\left(17^{\circ} \mathrm{C}\right)$ in mid-July (Fig. 1b) slightly after maximum air temperature. There were no clear differences in the soil temperatures at the sites; however, the temperatures were generally $5^{\circ} \mathrm{C}$ higher at the clear-cuts than in their surrounding forests.

The peat temperature readings in the Siikaneva fen began to increase on 14 April 2005, which suggests that the snow had already thawed by then in the open areas. However, Bergeron et al. (2008) noticed that the photosynthetically active growing season started about 1 week later and ended 1 week earlier at a clear-cut site compared to a mature site. Therefore, we can assume that the growing season was in the initial phase when we started our measurements. The small sizes of the deciduous shoots in the beginning of our measurement campaign similarly suggest that the growing season was in its early phase.

There were two rain-free and warm periods (Fig. 2b) that caused the soil water tension to increase for a short period of time (Fig. 2a) after mid-June and in early July. Except for these short droughts, the soil was fairly moist.

\subsection{Ground vegetation at the sites}

The results of the vegetation inventory, excluding the tree seedlings, are shown in Table 2. The total biomass of the above ground parts of the ground vegetation was approx. 
Table 2. Density $\left(\mathrm{g} \mathrm{m}^{-2}\right)$ and occurrence $(\%)$ of different species or ground vegetation types at the study sites. The species with site-specific gas exchange measurements are in bold face. The occurrence indicates the fraction of the sample plots in which the species were present.

\begin{tabular}{lcccc}
\hline & \multicolumn{2}{c}{ Infertile site } & \multicolumn{2}{c}{ Fertile site } \\
& Density $\left(\mathrm{g} \mathrm{m}^{-2}\right)$ & Occurrence $(\%)$ & Density $\left(\mathrm{g} \mathrm{m}^{-2}\right)$ & Occurrence $(\%)$ \\
\hline Calluna vulgaris & $\mathbf{2 2 1 . 0}$ & $\mathbf{4 5}$ & 0.0 & 0 \\
Vaccinium myrtillus & 0.0 & 0 & 4.8 & 32 \\
Vaccinium vitis-idaea & 29.6 & 90 & 39.4 & 53 \\
Empetrum nigrum & 26.3 & 25 & 0.0 & 0 \\
Rubus idaeus & 0.0 & 0 & $\mathbf{1 9 . 9}$ & $\mathbf{6 3}$ \\
Epilobium angustifolium & $\mathbf{1 9 . 7}$ & $\mathbf{3 5}$ & $\mathbf{5 8 . 4}$ & $\mathbf{6 3}$ \\
Deschampsia flexuosa & 0.1 & 5 & $\mathbf{7 3 . 2}$ & $\mathbf{7 4}$ \\
Other grasses & 0.0 & 0 & 0.8 & 21 \\
Melanpyrum pratense & 0.0 & 0 & 6.1 & 47 \\
Trientalis europea & 0.0 & 0 & 4.3 & 26 \\
Other herbs & 0.0 & 0 & 0.1 & 5 \\
Mosses & 63.8 & 90 & 34.2 & 79 \\
Total & $\mathbf{3 6 0 . 5}$ & & $\mathbf{2 4 1 . 2}$ & \\
\hline
\end{tabular}

$360 \mathrm{~g} \mathrm{~m}^{-2}$ and $240 \mathrm{~g} \mathrm{~m}^{-2}$ at the infertile and fertile sites, respectively. The high value of the infertile site can be explained mainly by the wooden parts of Calluna vulgaris. If mosses are considered perennial, $94 \%$ of the vegetation at the infertile site composed of species with perennial leaves, while the same value for the fertile site was only 27\%. At the infertile site, C. vulgaris, Vaccinium vitis-idaea L., Empetrum nigrum and E. angustifolium had the highest biomass of the vascular species. Vaccinium vitis-idaea and mosses of a different kind were found most frequently at the infertile site. At the fertile site, the most frequent species were grasses (most commonly D. flexuosa and Calamagrostis sp.), R. idaeus and E. angustifolium.

Mosses were denser at the infertile site. Pleurozium schreberi and Dicranum polysetum Sw. were the most common nonvascular species at the infertile site and at the fertile site, D. polysetum and Polytrichum Hedw. sp. were the most typical species.

\subsection{Photosynthesis}

\subsubsection{Initial slope of the light response curve}

Parameter $b_{i}$ in Eq. (1) describes the light level at which photosynthesis is half the maximum rate of photosynthesis, where the smaller parameter $b$ is, the more rapid photosynthesis saturates in the increasing light. The parameters $P_{\max }$ and $b$ are closely related and the values of the parameter $b$ tend to be too high to extrapolate high radiation conditions if it is estimated from measurements at low radiation intensities. In addition, the small number of measurements in one light response curve made the parameter estimation unstable. Therefore, we assumed that the species-specific $b$ values were constant throughout the season. The $b$ values used for
$R$. idaeus, E. angustifolium, $C$. vulgaris and D. flexuosa were 221, 280, 216 and $259 \mu \mathrm{mol} \mathrm{m}^{-2} \mathrm{~s}^{-2}$, respectively. Calluna vulgaris had the same range of values at the SMEAR II station below canopy. Kolari et al. (2006) estimated the parameter $b$ value to be 240 and Kulmala et al. (2008) to be $208 \mu \mathrm{mol} \mathrm{m}^{-2} \mathrm{~s}^{-2}$.

\subsubsection{The seasonal pattern of $P_{\max }$}

The $P_{\max }$ values of Epilobium angustifolium Calluna vulgaris, Rubus Idaeus and Deschampsia flexuosa had very clear seasonal patterns (Fig. 3). The species with annual leaves have clearly higher $P_{\max }$ values (maxima approx. $0.03 \mathrm{~g}_{\mathrm{CO} 2} \mathrm{~m}^{-2} \mathrm{~h}^{-1}$ ) than the perennial C. vulgaris (maximum $0.017 \mathrm{~g}_{\mathrm{CO} 2} \mathrm{~m}^{-2} \mathrm{~h}^{-1}$ ). The photosynthetic activity of Calluna vulgaris was still quite low in early June (Fig. 3a), possibly due to low temperatures (Fig. 1a). However, C. vulgaris recovered from winter very rapidly and its $P_{\max }$ values increased to more than double, close to the highest summertime values, in the first half of June. Already in August, the $P_{\max }$ of the sparse shoot decreased from the mid-summer maximum values while the dense shoot had relatively high $P_{\max }$ still in August before a rather linear decrease towards the late October (Fig. 3a).

Early in our campaign, the temperature sum was $390^{\circ} \mathrm{C}$ and all of the shoots of Epilobium angustifolium were still small. The $P_{\max }$ started to increase in June but there were differences in the timing of the maximum (Fig. 3b). At the infertile site, the maximum occurred in late June while the $P_{\max }$ at the fertile site did not decrease significantly before the end of the campaign. On the contrary, the other experimental shoot at the fertile site experienced a second growth that increased its $P_{\max }$ in July leading to the highest full-grown leaf 


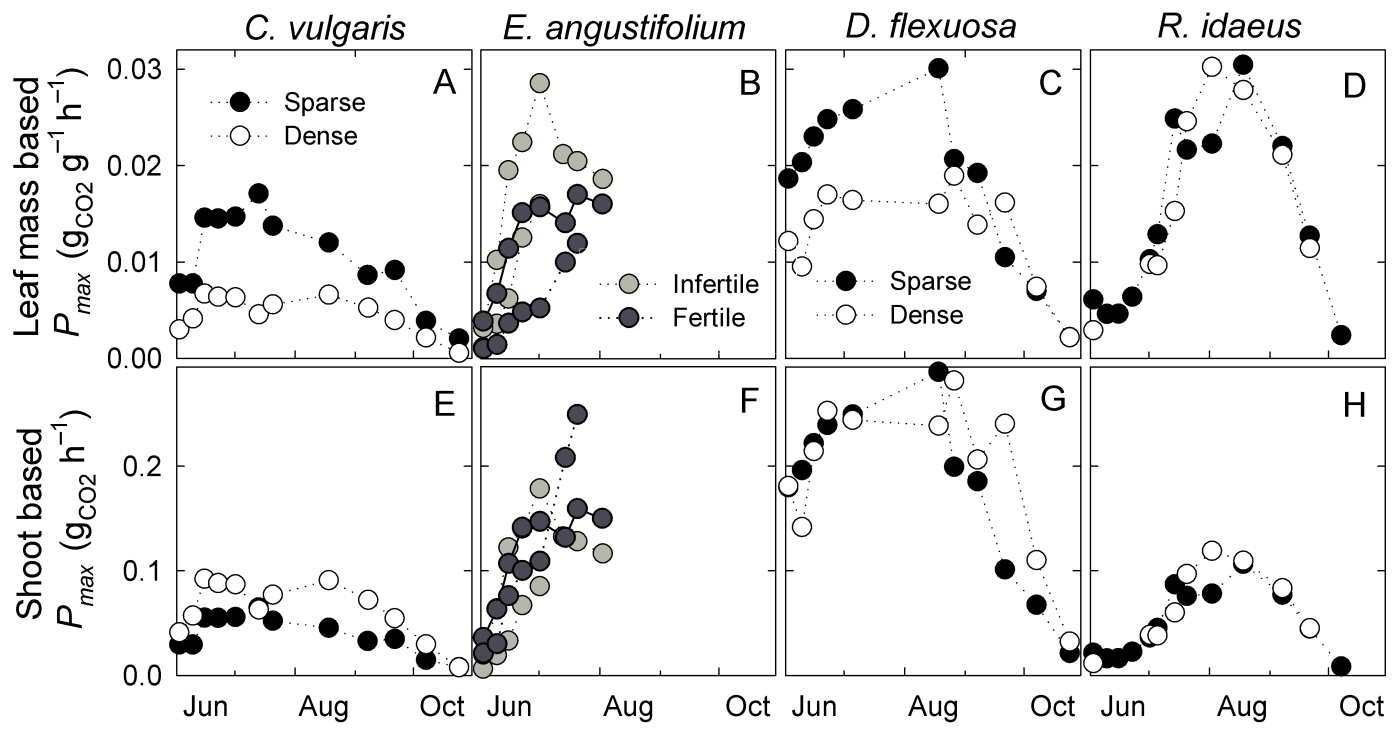

Fig. 3. Measured $P_{\max }$ values per full-grown leaf mass of four individual shoots of E. angustifolium, C. vulgaris, D. flexuosa and R. idaeus (A-D) and the individual measurements expressed without (E-H). The measured E. angustifolium shoots at the fertile site are marked with dark grey. Light grey indicates the infertile site (A and E). The experimental shoots of C. vulgaris and D. flexuosa were different in size. The leaf mass-based result of the smaller shoots are marked with black spheres ("Sparse") and of the larger shoots with empty spheres ("Dense").

mass $(18 \mathrm{~g})$ of the measured shoots as well as lowest leafmass based $P_{\max }$ values (lowest line in Fig. 3b).

We were forced to end the measurements and weight the shoots of E. angustifolium already in mid-July because the shoots began to show visible signs of approaching senescence and we did not want to lose the leaf mass information. Nevertheless, we observed that there is a wide variety in the individual timing of senescence in surrounding and nonexperimental shoots and some can be partly photosynthetically active even relatively late in autumn. Erley et al. (2002) found that nitrogen $(\mathrm{N})$ supply extends the life span of the leaf. In contrast to the shoots at the infertile site, the $P_{\max }$ values of the experimental shoots at the fertile site did not decrease significantly at the end of the campaign (Fig. 3b). However, our results cannot confirm nor reject the results of Erley et al. (2002), due to early ending of the campaign for E. angustifolium.

The $P_{\max }$ values of Deschampsia flexuosa were quite high in the beginning of our campaign (Fig. 3c) despite the visible shortness of the experimental shoots. The $P_{\max }$ values increased in June but unfortunately, the photosynthetic signal was very noisy during the hottest weeks in midsummer. Therefore, we rejected several measurements, which resulted in a more than 1 month gap in the data. The reason behind the clearly weaker quality of data with the grasses was the different measuring setup, as described earlier. High and fluctuating soil $\mathrm{CO}_{2}$ fluxes could have disturbed the photosynthetic signal. The measured $P_{\max }$ values were at their highest in mid-August and decreased intensively, being near zero, in October.
Early in the campaign, our 1-year-old experimental shoots of $R$. idaeus were short and the leaves small. The $P_{\max }$ values started to increase as late as on 22 June (Fig. 3d). The daily average temperature had been then over $10^{\circ} \mathrm{C}$ for 10 days and the 5 days running average had been over $13^{\circ} \mathrm{C}$ for six clear and sunny days. The first decrease in the $P_{\max }$ values was observed on 9 September when the length of the light hours (PAR $>10 \mu \mathrm{mol} \mathrm{m}^{-2} \mathrm{~s}^{-2}$ ) had decreased from 15.5 to $13.5 \mathrm{~h} \mathrm{day}^{-1}$ and the daily minimum temperatures had decreased since the previous measurement (from $13.5^{\circ} \mathrm{C}$ to $9.5^{\circ} \mathrm{C}$ ). However, the temperatures had already decreased since mid-June (Fig. 1a).

The photosynthetic and growth responses of trees are widely studied, due to their universality. Rubus idaeus is the only species studied here that has a long history of manipulation and follow-up studies, since it is commercially valuable. For example, Carew et al. (2003) found that the photoperiod did not significantly affect the growth rate, but increased temperature resulted in an increased rate of vegetative growth, the optimum temperature being approx. $25^{\circ} \mathrm{C}$ or below. Sonsteby and Heide (2008) also studied $R$. idaeus under natural summer daylight conditions and found that temperature clearly affects positively shoot growth.

Both $R$. idaeus and $C$. vulgaris showed individual reaction to drought. One of the shoots of both species showed a decreasing photosynthetic activity with increasing soil-water tension in July (Fig. 3a and d). At the same time, the other shoots showed no particular decrease. Half of the E. angustifolium shoots were also affected by the drought (Fig. 3b) that was maximal on 13 July (Fig. 2). The other shoot at the 
infertile site did not recover from the drought, but the one at the fertile site increased again its $P_{\max }$ value after the drought was over on 20 July. The individual reactions to the drought might be due to different shoot-root ratio, which affects the ability to withstand drought stress. Also microsite variation in the soil affects water availability, but the subject still needs further study.

The shoots of $R$. idaeus were one year old and it did not produce any flowers while flowering of E. angustifolium lasted nearly the entire campaign. Calluna vulgaris flowered in August and September. However, we did not notice any change in the photosynthesis that could be connected to flowering.

\subsubsection{The level of $P_{\max }$ of different sized shoots}

The level of full-grown leaf mass-based $P_{\max }$ values (Eq. 1) of the four E. angustifolium shoots (Fig. 3b) differed substantially throughout the measuring period (e.g. between 0.005 and $0.029 \mathrm{~g}_{\mathrm{CO} 2} \mathrm{~g}^{-1} \mathrm{~h}^{-1}$ on 1 July). The shoot-based values (Fig. 3f) were similar (between 0.09 and $0.18 \mathrm{~g}_{\mathrm{CO} 2} \mathrm{~h}^{-1}$ on 1 July). There were no clear visible differences in the shoots at the two clear-cut sites with the exception of size. The ones at the fertile site were taller, causing the individual $P_{\max }$ values to be slightly higher than those at the poor site. However, the status was reversed in the mass-specific inspection - probably a result of higher self-shading due to higher leaf mass (Fig. 3b). The shoots were quite identical at the poor site (masses $4.6 \mathrm{~g}$ and $5.4 \mathrm{~g}$ ). However, the smaller shoot already showed significantly lower $P_{\max }$ values early in the campaign before it accidentally died in early July. At the fertile site, the shoots were different sizes (18.0 g and 8.1 g) late in the campaign, due to secondary growth that began in early July in the larger one. The full-grown leaf mass-based $P_{\max }$ values of the dense shoot were very low, again probably due to high levels of self-shading. The self-shading or other limitations apparently had such a significant effect that the unstandardized results were more similar within species than the massbased results.

Epilobium angustifolium was the only species that grew at both the fertile and infertile sites in this study. Erley et al. (2001) found that under low nitrogen (N) supply, the leaves of some grasses had higher amounts of vascular bundles and fibrous cells and lower amounts of intercellular space and therefore higher densities of the leaves. The different composition and density of leaves may also explain the unexpected differences in the mass-specific expression of our results with E. angustifolium. In contrast to this study, several others found that the rates of photosynthesis and leaf respiration per leaf weight, specific leaf area and leaf mass ratio are higher in plants grown in high $\mathrm{N}$ soils (Field et al., 1983; Field and Mooney, 1983; Masarovicova et al., 2000; Poorter et al., 1995). Nevertheless, the difference in fertility did not significantly affect the rate of photosynthesis in this study.
Calluna vulgaris had substantially lower $P_{\max }$ values than the other species, as determined both for individual and leaf mass. The dense $C$. vulgaris shoot $(27.8 \mathrm{~g})$ had substantially lower leaf mass-based $P_{\max }$ values than the sparser shoot $(8.6 \mathrm{~g}$, Fig. 3a) while the dense shoot assimilated totally more than the sparse shoot (Fig. 3e). Accordingly, we again observed that the shoots had more similar levels of photosynthesis when compared based on individual than on fullgrown leaf mass. Rubus idaeus did not clearly show this type of phenomenon, but the shoots did not differ greatly. They had $3.0 \mathrm{~g}$ and $3.4 \mathrm{~g}$ of leaves, the smaller having slightly less total photosynthesis (Fig. 3h) as well as higher full-grown leaf mass-specific $P_{\max }$ values (Fig. 3d).

Comparison between the mass-based measurements of $D$. flexuosa indicates that grass populations also have some self-shading. The sparser population $\left(130 \mathrm{~g} \mathrm{~m}^{-2}\right)$ occasionally showed leaf mass-based $P_{\max }$ values twice as high as those of the denser population $\left(201 \mathrm{~g} \mathrm{~m}^{-2}\right.$, Fig. 3c), except for the autumn measurements when the sparser population showed earlier senescence. However, we again observed that there is less variation between the results without any normalizing on full-grown leaf mass (Fig. $3 \mathrm{c}$ and g). Woldedge observed the same already in 1973 and concluded that the decline in the photosynthetic activity of ryegrass leaves in a rapidly growing sward is due to the intense shading during their expansion.

These results indicate that the level of photosynthesis of different-sized individuals measured in this study is more equal than the mass-based values implying that the speciesspecific rate of photosynthesis is rather similar regardless of size or leaf area or leaf biomass of that individual. The earlier discussed effect of self-shading could be one explanation for the various leaf mass-specific levels of photosynthesis. Self-shading creates a heterogonous light environment that influences both rate of photosynthesis and the acclimation to the contrasting light environment. Light availability affects the relationship between leaf nitrogen concentration, light saturated photosynthetic activity and diurnal carbon balance (Hirose and Werger, 1987). Acclimation of photosynthesis to self-shading occurs even in mature leaves (Ishida et al., 1999). Declining leaf photosynthetic activity is connected to leaf position, light availability, allocation of nitrogen (Field, 1983) and chlorophyll to upper leaves (Ishida et al., 1999). On the other hand, there could be a physiological factor that limits photosynthesis in the measured species at ground level. The water transport of these species or root system, for example, may not be capable of efficiently supplying shoots with high leaf mass.

\subsubsection{Estimating photosynthetic activity}

The $P_{\max }$ values of Calluna vulgaris determined per fullgrown leaf mass fitted well with the estimated $\bar{P}_{\mathrm{max}, i}(t)$ based on the state of development (Fig. 4a, Eq. 4). However, in early spring $\bar{P}_{\max , i}(t)$ resulted in underestimation and on 


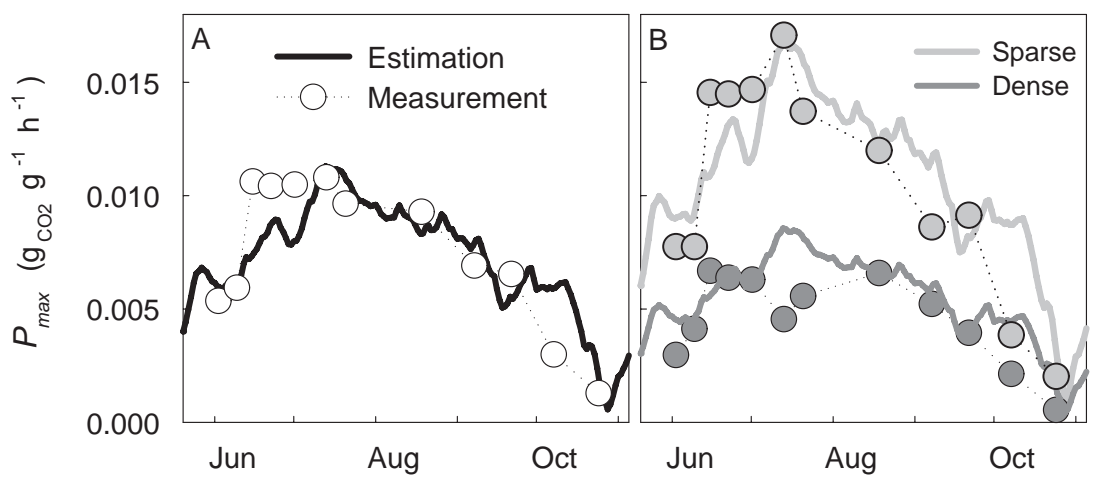

Fig. 4. Mass-based $\left(\bar{P}_{\max }(t)\right)$ values (lines) estimated from the state of development (Eq. 4) and measured $P_{\max }$ values (spheres) of $C$. vulgaris. (A) The average values, (B) both measured shoots and separately estimated $\left(\bar{P}_{\max }(t)\right)$ values. The dense shoot (dark grey) is shows a drought effect in July.

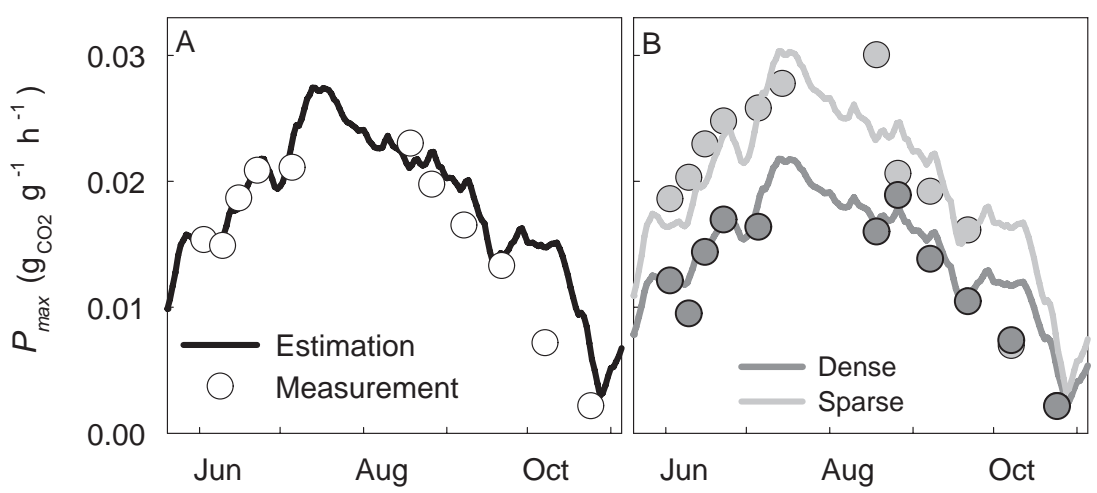

Fig. 5. Mass-based $\left(\bar{P}_{\max }(t)\right)$ values (lines) estimated from the state of development (Eq. 4) and measured $\bar{P}_{\text {max }}(t)$ values (spheres) of D. flexuosa. (A) The average values and (B) both measured shoots and separately estimated $\bar{P}_{\max }(t)$ values.

7 October the estimated values were higher than the measured values. The difference in autumn may be explained by the frost events occurring during the previous night which temporarily decreased the photosynthetic activity. On the other hand, the air temperature was not measured directly at either studied sites and, therefore, the small differences in site-specific micro-climates might affect the phenology of C. vulgaris and all other studied species as well.

When the shoots were examined separately, we noticed that the measurements of the sparse shoot followed $\bar{P}_{\max , i}(t)$ more closely than the measurements of the dense shoot which showed an early peak in the measured $P_{\max }$ values before a decrease in midsummer (Fig. 4b) at the same time that the short drought appeared (Fig. 2). Due to this decrease, we fitted the model based on the measurements before the drought (1 July) instead of the highest measurement (18 August). This resulted in a close fit between the estimation and the measurements except for the drought period and for the second last measurement in autumn. The overestimation in the model was presumably again a result of the frost that occurred during the previous night.
Deschampsia flexuosa, which has a relatively low growth rate for a grass, also followed $\bar{P}_{\max , i}(t)$ (Fig. 5a, Eq. 4) even though its leaves are deciduous. Here, we had to perform the fitting based on the measurement in late June, because the midsummer values were missing. The average of leaf mass-based $P_{\max }$ values fits with the modelled values better than any of the individual shoots (Fig. 5b). Again, there was an overestimation in the autumn, similar to that observed in C. vulgaris. The measured $P_{\max }$ in the sparser population was higher than the estimation early in the campaign, having the highest measured photosynthetic activity in August.

The measured whole plant $P_{\max }$ values of Rubus idaeus and Epilobium angustifolium did not follow the modelled $\bar{P}_{\text {max }, i}(t)$ that was based on temperature history. The highest measured $P_{\max }$ of $R$. idaeus as well as the accomplishment of maximal leaf area is later than the peak in $S$ (Eq. 3). The last two measurements with full leaf area seemed to follow the temperature history but this needs further study as well as introducing the species-specific leaf area increment into the model because the growth of $E$. angustifolium, for example, takes place earlier than $R$. idaeus. 


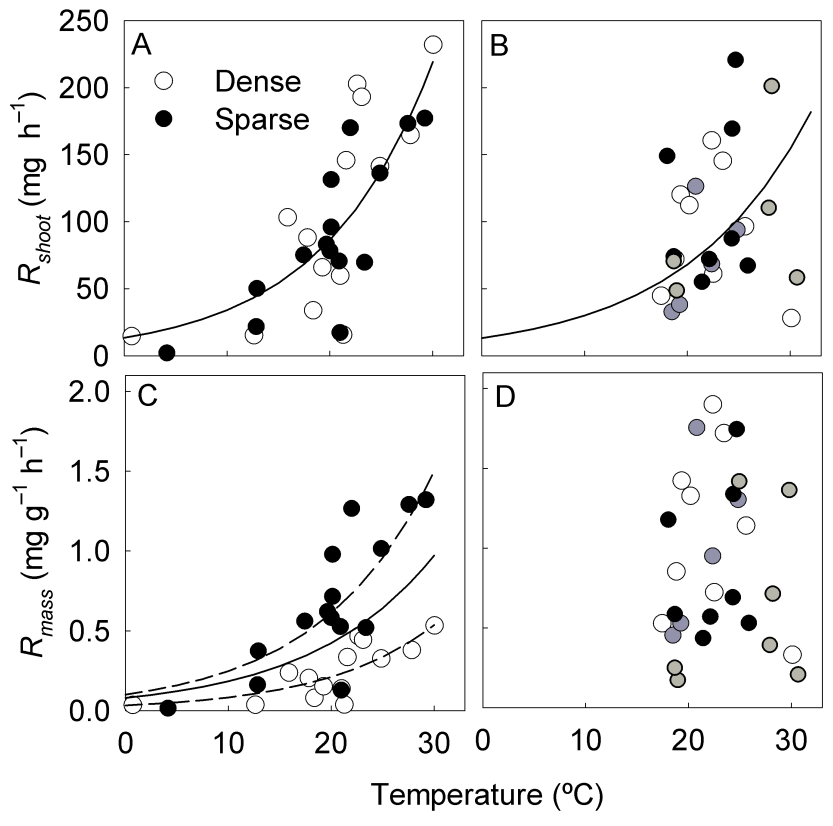

Fig. 6. Respiration against temperature of $C$. vulgaris (A and $\mathbf{C})$ and E. angustifolium (B and $\mathbf{D}$ ) of the measured shoots (upper panels) and based on full-grown leaf mass (lower panels). Individual shoots are marked with spheres of different colours. The fittings for both shoots are marked with the dashed lines and the average fitting with solid line in panel (C).

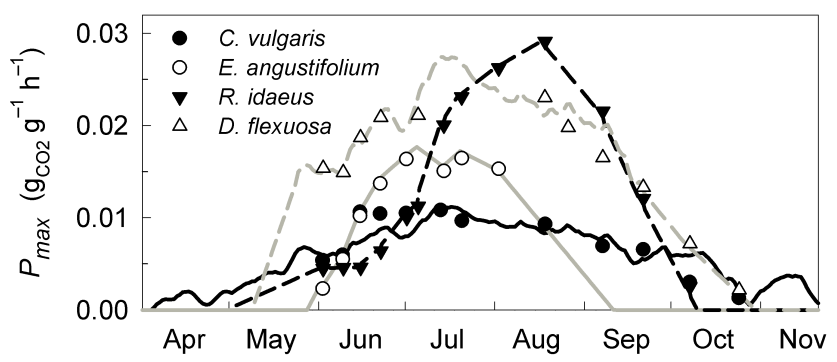

Fig. 7. Measured average $P_{\max }$ values for C. vulgaris, E. angustifolium, D. flexuosa and $R$. idaeus are marked with symbols. The daily $P_{\max }$ values used in the upscaling (lines) of E. angustifolium and $R$. idaeus are linearly interpolated from the measurements, whereas values of $C$. vulgaris and D. flexuosa follow the state of development (Eq. 4).

\subsection{Respiration}

Calluna vulgaris is a small shrub with abundant wooden biomass and perennial leaves. As a result, $C$. vulgaris has the lowest mass-specific level of respiration but the temperature response was similar to that of the other species $\left(Q_{10}\right.$ in Table 3). Leaves with high nitrogen content have high maintenance requirements, and consequently they typically have higher dark respiration than low-nitrogen leaves and, therefore, lose more carbon in respiration (Chapin et al.,
Table 3. Fitted parameter values for the temperature dependence of respiration.

\begin{tabular}{lccc}
\hline & $\begin{array}{c}R_{0} \\
\mathrm{mg} \mathrm{g}^{-1} \mathrm{~h}^{-1}\end{array}$ & $Q_{10}$ & $r^{2}$ \\
\hline Calluna vulgaris & 0.08 & 2.3 & 0.33 \\
Epilobium angustifolium & 0.05 & 3 & 0.01 \\
Rubus idaeus & 0.11 & 2.5 & 0.08 \\
\hline
\end{tabular}

1987). Epilobium angustifolium and Rubus idaeus showed wide variation in respiration values, but no clear temperature sensitivity (Fig. 6b and d). Frantz et al. (2004) found that whole-plant respiration of rapidly growing plants had low sensitivity to temperature. However, the narrow temperature range and the two low values near $30^{\circ} \mathrm{C}$ might also be the reason for the week temperature response and low $r^{2}$ values (Table 3).

Reich et al. (1998) found that mass-based leaf dark respiration rate $\left(R_{\text {mass }}\right)$ was positively related to specific leaf area and mass-based net photosynthetic activity as well as to leaf nitrogen mass, while the respiration rate decreased sharply with increasing leaf life span. Larsen et al. (2007) found that even the whole ecosystem respiration depends on the photosynthesis of $C$. Vulgaris at a temperate heath. Our results indicate the same: the measured respiration rates of above ground parts closely followed to the photosynthetic rate and C. vulgaris, with the longest life span, had the lowest respiration rates.

However, the averaging of the species-specific respiration was again problematical because the individual shoots had a different mass-based level of respiration. The shoots of $\mathrm{Cal}$ luna vulgaris had a similar type of response to temperature, but the $R_{\text {mass }}$ level was different (Fig. 6c), while the total respiration of individual shoots $\left(R_{\text {shoot }}\right)$ were more similar (Fig. 6a). The temperature dependence that was somewhat seen in the total respiration of all shoots (Fig. 6b) was lost, when the results were based on above ground mass (Fig. 6d).

\subsection{Upscaled GPP and $R_{e}$}

For upscaling, we used the estimated daily $\bar{P}_{\text {max }, i}(t)$ values of Calluna vulgaris and Deschampsia flexuosa that followed the state of development (Eq. 4, Fig. 7). We did not measure the photosynthesis of $D$. flexuosa before early June but we assumed that it remained zero for some time after the snow melted, even the temperature increased. Therefore, we set the $\bar{P}_{\max , i}(t)$ values to increase linearly from zero, starting from 9 May until 20 May and thereafter to follow the temperature history. Rubus idaeus was set to increase linearly from 1 May to the first measurement (2 June) when $P_{\max }$ was still very low. The shoots of Epilobium angustifolium began to senescence already in midsummer but part of the leaves may 


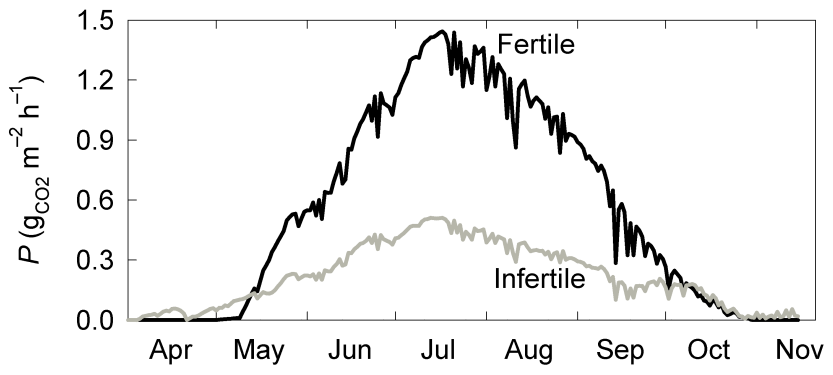

Fig. 8. Upscaled daily maximum photosynthesis rate of the measured species at the infertile and fertile sites.

have remained green in some individuals until late autumn. We decided to extrapolate the $\bar{P}_{\max , i}(t)$ values for E. angustifolium linearly from the last measurement on 2 July to be zero on 12 September and thereafter. Using these speciesspecific daily $\bar{P}_{\max , i}(t)$ values, average full-grown leaf mass and hourly average PAR measurements we upscaled (Eq. 5) the photosynthetic production to be $2800 \mathrm{~g} \mathrm{CO}_{2} \mathrm{~m}^{-2} \mathrm{y}^{-1}$ (760 $\mathrm{g} \mathrm{C} \mathrm{m}^{-2} \mathrm{y}^{-1}$ ) at the fertile site and $1100 \mathrm{~g} \mathrm{CO}_{2} \mathrm{~m}^{-2} \mathrm{y}^{-1}$ (300 $\mathrm{g} \mathrm{C} \mathrm{m}^{-2} \mathrm{y}^{-1}$ ) at the infertile site (Fig. 8) where Calluna vulgaris and E. angustifolium fixed 244 and $55 \mathrm{~m}^{-2} \mathrm{y}^{-1}$, respectively. The species-specific estimations at the fertile site are 105,163 and $494 \mathrm{~g} \mathrm{C} \mathrm{m}^{-2} \mathrm{y}^{-1}$ for R. idaeus, E. angustifolium and $D$. flexuosa, respectively. If we consider only the time between the first and last species-specific measurement without any assumptions for early spring and late autumn, we obtain $2500 \mathrm{~g}$ and $930 \mathrm{~g} \mathrm{CO}_{2} \mathrm{~m}^{-2} \mathrm{y}^{-1}$ (680 and $250 \mathrm{~g} \mathrm{C}$ $\left.\mathrm{m}^{-2} \mathrm{y}^{-1}\right)$ at the fertile and infertile site, respectively.

The used process-based upscaling procedure is very sensitive to biomass and it does not take shading into account. Many species such as Vaccinium vitis-idaea and mosses were missing from the analysis since measuring all species and high variation between individuals would be impossible. There are differences in the level and in the reactions to environmental factors within species. It is also somewhat probable that the $b_{i}$ (Eq. 1) is changing seasonally even if we assumed it to be constant. In addition, the time constant ( $\tau$, Eq. 3) needs further studies too.

However, our result is within the range of other net ecosystem scale results published on young forests. Herbaceous plants and woody shrubs were estimated to uptake 315 and $172 \mathrm{~g} \mathrm{C} \mathrm{m}^{-2}$, respectively at a 5-y-old vegetated clearcut in subboreal British Columbia (Pypker and Fredeen, 2002). Using EC measurements, gross ecosystem production including tree seedlings (GEP) was $316 \mathrm{~g} \mathrm{C} \mathrm{m}^{-2} \mathrm{y}^{-1}$ in Québec (Bergeron et al., 2008), $435 \mathrm{~g} \mathrm{C} \mathrm{m}^{-2} \mathrm{y}^{-1}$ in Vancouver (Humphreys et al., 2006) and gross primary production (GPP) $323 \mathrm{~g} \mathrm{C} \mathrm{m}^{-2} \mathrm{y}^{-1}$ in southern Finland (Kolari et al., 2004) at young clear-cut sites. In southwestern United States, the GPP was $858 \mathrm{~g} \mathrm{C} \mathrm{m}^{-2} \mathrm{a}^{-1}$ after fire (Dore et al., 2008). Noormets et al. (2007) showed that time-integrated fluxes from May to October in managed forests in northern Wis- consin (USA) in 2002 were 699, 1052, and $460 \mathrm{~g} \mathrm{C} \mathrm{m}^{-2}$ at 3-, 8-, and 12-year-old sites, respectively. However, the GPP depends on climate, fertility and species composition and the process-based method has some shortcomings as highlighted earlier. Therefore, it would be beneficial to further test the different methods simultaneously.

Our measurements showed that the aboveground elements of Calluna vulgaris released $68 \mathrm{~g} \mathrm{C} \mathrm{m}^{-2}$ at the infertile site during the snow-free period (18 April-21 November), when modelled with the temperature dependence curve (Eqs. 2 and 6), hourly average temperatures and the average aboveground biomass (Table 2). The aboveground parts of Epilobium angustifolium released $7 \mathrm{~g} \mathrm{C} \mathrm{m}^{-2}$ at the infertile site and $22 \mathrm{~g} \mathrm{C} \mathrm{m}^{-2}$ at the fertile site, using the same calculation method. The aboveground parts of Rubus idaeus released $12 \mathrm{C} \mathrm{m}^{-2}$ at the fertile site. The value of $C$. vulgaris seems very high in comparison to carbon fixed per leaf mass $(33 \%)$. This was probably caused by the fitting of the respiration values: the model apparently results in overestimation of the respiration at lower temperatures (below $12^{\circ} \mathrm{C}$ ). The model might also overestimate the respiration during night time because respiration has been observed to be the highest after photosynthesis and decreasing in prolonged darkness (Azcón-Bieto and Osmond, 1983). In addition, the fit of the temperature dependence curve included lot of uncertainty.

The net productions $\left(\mathrm{GPP}_{i}-R_{i}\right)$ of $R$. idaeus and $E$. angustifolium were several times higher than their standing biomasses. The missing emissions can be partly explained by the release of carbon in the senescence that was not recorded in our sequence. The species are perennial despite their annual leaves or entire aboveground parts and, therefore, they also store carbon below ground in their root systems. The net production of Calluna vulgaris $\left(\mathrm{GPP}-R_{e}\right)$ was $20 \%$ lower than the standing biomass. The small difference in $C$. vulgaris might be explained by the high fraction of wooden biomass that has low cost of vital functions.

\section{Conclusions}

Common ground vegetation species in early succession, Epilobium angustifolium, Deschampsia flexuosa, Rubus idaeus and Calluna vulgaris, have clear, species-specific seasonal cycles in their $P_{\max }$ levels. The $P_{\max }$ of $C$. vulgaris and $E$. angustifolium peaked in June and July whereas in $R$. idaeus the $P_{\text {max }}$ peaked as late as August. A model, based on temperature history, was able to predict the photosynthetic activity of $C$. vulgaris when soil moisture conditions were normal. The activity of Deschampsia flexuosa with its deciduous leaves also followed the temperature history within the time frame of our measurement campaign. Some shoots of $C$. vulgaris and R. idaeus decreased their photosynthetic activity during drought, while the drought did not affect the other shoots. Individual shoots of E. angustifolium also showed differences in the reaction to drought. 
Calluna vulgaris is a small shrub with abundant wooden biomass and perennial leaves. As a result, $C$. vulgaris has the lowest mass-specific level of photosynthesis and respiration of the plant species in our study. However, temperature response of respiration was similar to that in the other species. Whole-plant respiration of $R$. idaeus and especially $E$. angustifolium did not show a clear sensitivity to temperature.

The total photosynthesis and respiration were more concomitant between the plant individuals than the results based on full-grown leaf biomass. This may be the result of significant self-shading in deep crown that increases with leaf mass or other limitations that require additional research.

We upscaled the species-specific process rates by species composition, and integrated fixed and respired $\mathrm{CO}_{2}$ of measured species over the entire growing season by continuous temperature and radiation measurements. The results showed that from very poor and very fertile clear-cut site, the potential present range of photosynthetic production of ground vegetation was $300-760 \mathrm{~g} \mathrm{C} \mathrm{m}^{-2} \mathrm{y}^{-1}$. It is within the same range of other ecosystem scale studies at young sites. The process-based upscaling used in this study enables extrapolation and estimation of the future $\mathrm{CO}_{2}$ exchange of ground vegetation. However, the method still has shortcomings (e.g. inaccuracy in estimated biomass and inaccessibility to all species). Avoiding these possible causes of error is very laborious. Therefore, integrated use with $\mathrm{EC}$ technique would be advantageous.

Acknowledgements. This research was supported by the Academy of Finland Centre of Excellence program (project number 1118615), Academy of Finland projects number 213093 and 206085, Infrastructure for Measurements of the European Carbon Cycle (IMECC) founded by European Commission and Integrated Carbon Observating System (ICOS). Sami Haapanala is greatly acknowledged for providing the temperature measurements at the Siikaneva fen.

Edited by: B. D. Sigurdsson

\section{References}

Azcón-Bieto, J. and Osmond, C. B.: Relationship between photosynthesis and respiration. The effect of carboxydrate status on the rate of $\mathrm{CO}_{2}$ production by respiration in darkened and illuminated wheat leaves, Plant Physiol, 71, 574-578, 1983.

Bergeron, O., Margolis, H. A., Coursolle, C., and Giasson, M.-A.: How does forest harvest influence carbon dioxide fluxes of black spruce ecosystems in eastern North America?, Agric. For. Meteorol., 148, 537-548, 2008.

Cajander, A. K.: The theory of forest types, Acta For. Fen., 29, 1-108, 1926.

Carew, J. G., Mahmood, K., Darby, J., Hadley, P., and Battey, N. H.: The effect of temperature, photosynthetic photon flux density, and photoperiod on the vegetative growth and flowering of 'Autumn Bliss' raspberry, J. Am. Soc. Hortic. Sci., 128, 291296, 2003.
Chabot, B. F. and Hicks, D. J.: The ecology of leaf life spans, Ann. Rev. Syst., 13, 229-259, 1982.

Chapin III, F. S., Bloom, A. J., Field, C. B., and Waring, R. H.: Plant Responses to Multiple Environmental Factors, Bioscience, 37, 49-57, 1987.

DeLucia, E., Heckathorn, S. A., and Day, T. A.: Effects of soil temperature on growth,biomass allocation and resource acquisition, New Phytol., 120, 543-549, 1992.

Dore, S., Kolb, T. E., Montes-Helu, M., Sullivan, B. W., Winslow, W. D., Hart, S. C., Kaye, J. P., Koch, G. W., and Hungate, B. A.: Long-term impact of a stand-replacing fire on ecosystem $\mathrm{CO}_{2}$ exchange of a ponderosa pine forest, Global Change Biol., 14, 1-20, 2008.

Drebs, A., Nordlund, A., Karlsson, P., Helminen, J., and Rissanen, P.: Climatological Statistics of Finland 1971-2000, Climatological statistics of Finland 2001, Finnish Meteorological Institute, Helsinki, 2002.

Erley, G. S. A., Rademacher, I., and Kuhbauch, W.: Leaf anatomy of a fast- and a slow-growing grass as dependent on nitrogen supply, J. Agron. Crop Sci., 187, 231-239, 2001.

Erley, G. S. A., Rademacher, I., and Kuhbauch, W.: Leaf life span of a fast- and a slow-growing grass as dependent on nitrogen supply, J. Appl. Bot.-Angew. Bot., 76, 8-12, 2002.

FAO-Unesco: Soil map of the world, revised legend, World Soil Resources Report 60, 1990.

Field, C. B.: Allocating leaf nitrogen for the maximization of carbon gain: leaf age as a control on the allocation program, Oecologia, 56, 341-347, 1983.

Field, C. and Mooney, H. A.: Leaf age and seasonal effects on light, water, and nitrogen use efficiency in a calif ornia shrub, Oecologia, 56, 348-355, 1983.

Field, C., Merino, J., and Mooney, H. A.: Compromises between water-use efficiency and nitrogen-use efficiency in five species of California evergreens, Oecologia, 60, 384-389, 1983.

Frantz, J. M., Cometti, N. N., and Bugbee, B.: Night temperature has a minimal effect on respiration and growth in rapidly growing plants, Ann. Bot.-London, 94, 155-166, 2004.

Fredeen, A. L., Waughtal, J. D., and Pypker, T. G.: When do replanted sub-boreal clearcuts become net sinks for $\mathrm{CO}_{2}$ ?, For. Ecol. Manage., 239, 210-216, 2007.

Hari, P. and Kulmala, M.: Station for measuring EcosystemAtmosphere Relations (SMEARII), Bor. Env. Res., 10, 315-322, 2005.

Hirose, T. and Werger, M. J. A.: Maximizing daily carbon photosynthesis with respect to the leaf nitrogen allocation pattern in the canopy, Oecologia, 72, 520-526, 1987.

Humphreys, E. R., Black, T. A., Morgenstern, K., Cai, T., Drewitt, G. B., Nesic, Z., and Trofymow, J. A.: Carbon dioxide fluxes in coastal Douglas-fir stands at different stages of development after clearcut harvesting, Agric. For. Meteorol., 140, 6-22, 2006.

Ishida, A., Uemura, A., Koike, N., Matsumoto, Y., and Ang, L. H.: Interactive effects of leaf age and self-shading on leaf structure, Photosynthetic capacity and chlorophyll fluorescence in the rain forest tree, Dryobalanops aromatica, Tree Physiol., 19, 741-747, 1999.

IPCC: Contribution of Working Group I to the Fourth Assessment Report of the Intergovernmental Panel on Climate Change, in: Cambridge University Press, edited by: Solomon, S., Qin, D., Manning, M., Chen, Z., Marquis, M., Averyt, K., Tignor, M. M. 
B., and Miller, H. L., Cambridge, UK and New York, USA, 800 pp, 2007.

Jalonen, J., Vanha-Majamaa, I., and Tonteri, T.: Optimal sample and plot size for inventory of field and ground layer vegetation in a mature Myrtillus-type boreal spruce forest, Ann Bot Fenn, 35, 191-196, 1998.

Johnson, D. W. and Curtis, P. S.: Effects of forest management on soil $\mathrm{C}$ and $\mathrm{N}$ storage: meta analysis, Forest Ecol. Manag., 140, 227-238, 2001

Kolari, P. Pumpanen, J., Rannik, U., Ilvesniemi, H., Hari, P., and Berninger, F.: Carbon balance of different aged Scots pine forests in Southern Finland, Global Change Biol., 10, 1106-1119, 2004.

Kolari, P., Pumpanen, J., Kulmala, L., Ilvesniemi, H., Nikinmaa, E., Grönholm, T., and Hari, P.: Forest floor vegetation plays an important role in photosynthetic production of boreal forests, For. Ecol. Manag., 221, 241-248, 2006.

Kulmala, L., Launiainen, S., Pumpanen, J., Lankreijer, H., Lindroth, A., Hari, P., and Vesala, T.: $\mathrm{H}_{2} \mathrm{O}$ and $\mathrm{CO}_{2}$ fluxes at the floor of a boreal pine forest, Tellus B, 60, 167-178, 2008.

Larsen, K. S., Ibrom, A., Beier, C., Jonasson, S., and Michelsen, A.: Ecosystem respiration depends strongly on photosynthesis in a temperate heath, Biogeochemistry, 85, 201-213, 2007.

Mäkelä, A., Hari, P., Berninger, F., Hänninen, H., and Nikinmaa, E.: Acclimation of photosynthetic capacity in Scots pine to the annual cycle of temperauture, Tree Physiol., 24, 369-376, 2004.

Masarovicova, E., Welschen, R., Lux, A., Lambers, H., Argalasova, K., Brandsteterova, E., and Caniova, A.: Photosynthesis, biomass partitioning and peroxisomicine $\mathrm{A}(1)$ production of Karwinskia species in response to nitrogen supply, Physiol. Plantarum, 108, 300-306, 2000.

Metla: Finnish Statistical Yearbook of Forestry, 2004, Finnish Forest Research Institute, 2004.

Michaelis, L. and Menten, M.: Die Kinetik der Invertinwirkung, Biochem. Z., 49, 333-369, 1913.

Noormets, A., Chen, J., and Crow, T. R.: Age-dependent changes in ecosystem carbon fluxes in managed forests in northern Wisconsin, USA, Ecosystems, 10, 187-203, 2007.

Palviainen, M., Finér, L., Mannerkoski, H., Piirainen, S., and Starr, M.: Responses of ground vegetation species to clear-cutting in a boreal forest: aboveground biomass and nutrient contents during the first 7 years, Ecol. Res., 20, 652-660, 2005.
Pelkonen, P. and Hari, P.: The dependence of the springtime recovery of $\mathrm{CO}_{2}$ uptake in Scots pine on temperature and internal factors, Flora, 169, 398-404, 1980.

Poorter, H., Vijver, C. van de, Boot, R. G., and Lambers, H.: Growth and carbon economy of a fast-growing and a slow-growing grass species as dependent on nitrate supply, Plant Soil, 171, 217-227, 1995.

Pearcy, R. W., Björkman, O,. Caldwell, M. M., Keeley, J. E., Monson, R. K., and Strain, B. R.: Carbon gain by plants in natural environments, Bioscience, 37, 21-29, 1987.

Pykälä, J.: Immediate increase in plant species richness after clearcutting of boreal herb-rich forests, Appl. Vegetat. Sci., 7, 29-34, 2004.

Pypker, T. G. and Fredeen, A. L.: Ecosystem $\mathrm{CO}_{2}$ flux over two growing seasons for a sub-Boreal clearcut 5 and 6 years after harvest, Agric. For. Meteorol., 114, 15-30, 2002.

Rannik, Ü., Altimir, N., Raittila, J., Suni, T., Gaman, A., Hussein, T., Holtta, T., Lassila, H., Latokartano, M., Lauri, A., Natsheh, A., Petaja, T., Sorjamaa, R., Yla-Mella, H., Keronen, P., Berninger, F., Vesala, T., Hari, P., and Kulmala, M.: Fluxes of carbon dioxide and water vapour over Scots pine forest and clearing, Agric. For. Meteorol., 111, 187-202, 2002.

Reich, P. B., Walters, M. B., Ellsworth, D. S., Vose, J. M., Volin, J. C., Gresham, C., and Bowman, W. D.: Relationships of leaf dark respiration to leaf nitrogen, specific leaf area and leaf life-span: a test across biomes and functional groups, Oecologia, 114, 471482, 1998.

Riutta, T., Laine, J., Aurela, M., Rinne, J., Vesela, T., Laurila, T., Haapanala, S., Pihlatie, M., and Tuittila, E. S.: Spatial Variation in Plant Community Functions Regulates Carbon Gas Dynamics in a Boreal Fen Ecosystem, Tellus B, 59, 838-852, 2007.

Ryyppö, A., Iivonen, S., Rikala, R., Sutinen, M.-L., and Vapaavuori, E.: Responses of scots pine seedlings to low root zone temperature in spring, Physiol. Plant., 102, 503-512, 1998.

Sønsteby, A. and Heide, O. M.: Temperature responses, flowering and fruit yield of the June-bearing strawberry cultivars Florence, Frida and Korona, Scientia Horticulturae, 119, 49-54, 2008.

Taiz, L. and Zeiger, E.: Plant Physiology. 3rd edition, Sinauer Associates, Sunderland MA, USA, 2002.

Van't Hoff, J. H.: Etudes de dynamique chemique, Frederik Muller \& Co., Amsterdam, 1884.

Woledge, J.: The photosynthesis of ryegrass leaves grown in a simulated sward, Annals of Applied Biology, 73, 229-237, 1973. 